\title{
How 'realistic' should global political theory be? Some reflections on the debate so far
}

\section{Introduction}

There is an air of paradox about the suggestion that it is time for global political theory to 'get real'. After all, 'realism' has long been regarded as providing the most revealing way to look at international politics: even those who want to move beyond it feel the need to say something in response to mid-twentieth century authors such as Niebuhr (1940, 1953), Morgenthau (1954) and Waltz (1959), for whom relations between states were chiefly characterised by conflicts of power and interest. Going back still further, the international realm was memorably characterised by Hobbes as a state of perpetual (hot or cold) war, in the absence of an overarching sovereign to keep its constituents in awe:

...in all times, Kings, and Persons of Soveraigne authority, because of their Independency, are in continuall jealousies, and in the state and posture of Gladiators; having their weapons pointing, and their eyes fixed on one another; that is, their Forts, Garrisons, and Guns upon the Frontiers of their Kingdomes; and continuall Spyes upon their neighbours; which is a posture of War. (Hobbes, 1985: 187-8)

Hobbes also explained what made this state of affairs tolerable: each sovereign 'solves' the basic political problem - getting us out of the dismal state of nature - for its own subjects, and although there are undoubtedly downsides to an international order made up of antagonistic states, these are not so great as to propel us towards instituting a global sovereign. We would therefore have to imagine some catastrophic series of events - intense global warming perhaps, or the arrival of aliens like those in the film Independence Day - in order to make submission to such a sovereign a rational necessity as Hobbes understands it.

Even if Hobbes, or his latter-day followers, only saw one half of the truth about international relations, to say that what we need to do is take 'realism' as applied to domestic politics and transpose it to the international sphere must sound (to use the English vernacular) a bit like carrying coals to Newcastle. But perhaps the recent spate of academic writing on global justice is so deformed by utopian thinking as to require this corrective? If so, we had better first be sure that the proposed remedy is sound, when applied to politics in general. So is there an identifiable political outlook that we can label 'realist', as some have claimed (see for example Galston, 2010, Sleat, 2013: esp. chs. 2-3, Philp, 2012, Rossi and Sleat, 2014), or is what we find instead a series of critiques with little in common other than their distaste for liberal political theory in the manner of Rawls? Before we can decide whether realism should be encouraged to 'go global', we need to be 
clearer both about the substance and about the merits of realism as applied in its original context, domestic politics (other assessments include Floyd, 2010, Horton, 2010, Honig and Stears, 2011, Baderin, 2014, Finlayson, 2015).

\section{Two concepts of realism}

The term 'realism' has multiple uses in moral and political philosophy (see Risse, 2016 for a discussion of 'moral realism, for example), but for present purposes I want to distinguish two broad

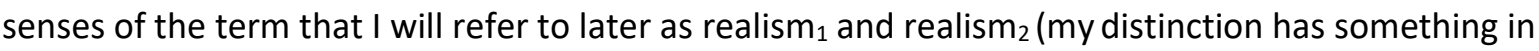
common with, though is not exactly the same as, the distinction that Baderin, 2014 draws between 'detachment' and 'displacement' realism). In the first of these, 'realism' is to be contrasted with utopianism. It counsels us to pay attention to how things actually are in the world, and to adjust any political recommendations we make in the light of this. For, example, it tells us to look hard at human nature and its emotional and cognitive limitations, and not to prescribe policies that require humans to act beyond these limits - for example to behave with complete impartiality towards all their fellows. It tells us to examine how political institutions actually work, as opposed to how we might hope that they would work - for example to look at the ends that bureaucracies in fact pursue as against the ends they are set up to pursue. It tells us to enquire into the conditions under which some favoured ideal can be realised, and those under which it cannot - for example into the socioeconomic conditions under which stable democracy is achievable. It tells us to look for the individual or collective agents who can reasonably be expected to promote the concrete aims that our political philosophy supports, and to consider revising those aims if no such agents can be found. And so on, across the board: realism in this sense proposes a close marriage between political philosophy and the social sciences, since the latter are going to be the most reliable sources of evidence about 'how things actually are', not just in the sense of 'how things stand now' but in the sense of 'what it is feasible to aim for and what isn' $\mathrm{t}^{\prime}$, looking across space and time more broadly. ${ }^{1}$

Realism understood in this way is not a fixed position: it is a comparative notion. From any given starting point, position A will seems more 'realistic' than position B, and position B more 'utopian' than position $A$, in cases where $B$ requires more radical changes to human behaviour, institutional performance, etc. than A does. There will be no political philosophy that is not in certain respects realistic - that is, we can always imagine an alternative to it that enlarges human possibilities still further. An interesting question, however, is whether we can say anything about how realistic political philosophy ought to be. This is going to depend on what we take its purpose to be - what kind of advice or enlightenment it aims to offer to its audience (see Risse, 2016 for a comparison of different views about the contribution that political philosophers should make to the political life of 
their societies). The more it seeks to be directly action-guiding, the more realistic it will need to be. There is room here, therefore, for different styles of political philosophy to co-exist at any time, though they will be in competition with each other over the correct answer to the question posed in the last sentence - how important it is for political philosophy to set out goals that its addressees can pursue here and now with some chance of success. ${ }^{2}$

In this first sense, then, when someone advocates that political philosophy should become more 'realistic', she has set her sights on some theory or group of theories and judged that, relative to that group, it is important for future work to take greater account of a set of practical constraints that have hitherto been ignored. In that respect it is more of a methodological recommendation than a substantive position, though the person advocating 'realism' is likely of course to have a substantive position that she wishes to defend by using that method. The second sense of realism is straightforwardly substantive: it is a claim about the nature of politics itself, and therefore of the kinds of ends that can be pursued by political means. It is contrasted not with 'utopianism', but with what is often now referred to as 'political moralism', following Bernard Williams (2005a). ${ }^{3}$ The negative claim, then, is that there is something in the very essence of politics that makes it inapt for pursuing moral goals, such as justice understood in its usual sense. What is the corresponding positive claim? Here different 'realists' seem to part company, or at least to emphasize different themes. One theme is political disagreement: politics exists because of a lack of consensus on what is to be done collectively. Each person, or each group, has different aims that they want to pursue, or different ways of understanding apparently shared goals like freedom or social justice. They cannot reach agreement on these goals, even after extensive deliberation; there is no wider perspective that they all share and that might provide the basis for consensus. The best they can hope for is compromise, but more likely one party will succeed in promoting its aims, through a collective decision taken at the expense of the others. Politics, therefore, has to be understood as a way of dealing with disagreement over ends by means of decisions that are imposed upon the losing side.

A second theme is the pursuit of power as an end in itself. Politics, on this view, is about winning power and exercising it over your competitors. Here the ends for which power is exercised matter less than its bare possession. Both views, then, present politics as a competitive struggle between opponents which rules out seeing it as a vehicle through which moral ideals - such as Rawlsian justice, understood as grounded in an overlapping consensus among citizens - can be pursued. However even realists about politics insist that it should not be reduced to the simple exercise of coercive power by some over others: it may involve domination, but it is not merely domination and 
nothing else. It also involves the making and accepting of legitimacy claims. Again, different authors develop this point in different ways. For Williams (2005a: 5-7) the satisfaction of what he calls the 'Basic Legitimation Demand' is what distinguishes politics as such from a 'situation of one lot of people terrorising another lot of people', and he goes on to lay down conditions that must be met if the Demand is to be satisfied in contemporary societies. This softens political realism considerably, since it immediately opens up the possibility (further explored in Miller, Forthcoming b) that something resembling Rawls' theory of justice might be recast as a theory of political legitimacy for modern liberal societies. Geuss (2008: 36 ) in contrast treats legitimation as simply one of the devices that those who hold power use to encourage the others to comply, and therefore as open ended in its content: 'the beliefs that lie at the base of forms of legitimation are often as confused, potentially contradictory, incomplete, and pliable as anything else, and they can in principle be manipulated, although in most cases not ad libitum' (further respects in which Williams and Geuss part company in their respective 'realisms' are usefully examined in Honig and Stears, 2011).

\section{Why realism ${ }_{2}$ is unrealistic: political disagreement and national identity}

Having distinguished these two senses of political realism, I now want to suggest that realism 2 is not in fact particularly 'realistic' by the standards of realism ${ }_{1}$. That is, realism 2 gives us a partial and onesided view of politics as it is practised in contemporary societies, and is therefore inadequate as a guide to the range of possibilities that we actually face. This will turn out to be important if we are contemplating applying the realist ${ }_{2}$ model globally. To begin with, realism $_{2}$ exaggerates the extent of political disagreement in the societies it pretends to describe. It fails to notice that on many important issues, both procedural and substantive, the overwhelming majority of citizens hold convergent views. There are at least two reasons why disagreement may appear to be deeper and more widespread than it actually is.

One is that political parties by necessity have to exaggerate the distance that separates them from their opponents. They have to pretend that the forthcoming election is the most momentous ever held, that our side and their side represent two incompatible visions of the future of the country whereas in fact, in contemporary democracies at least, the real contest for power is between parties whose policy differences are tiny: a percentage or two on or off the tax rate, a small shift of expenditure from one department to the other. There may be particular occasions where it really does matter which party is in power: for example, parties might disagree over whether to intervene in a foreign conflict. But they will do so against a background of agreement on general principles covering such interventions, some so 'obvious' as to barely need spelling out (for examples that having armed forces for purposes of national defence is legitimate, that large scale violations of 
human rights are a matter of international concern, that any intervention that is undertaken should avoid civilian casualties, etc. etc.). These views will be widely shared by citizens at large and by all political parties that are serious contenders for power. They are part of the unspoken consensus without which no liberal democracy could function. Of course they are by no means unchallengeable, and there will be a few people - wholehearted pacifists, extreme nationalists who may challenge one or more of them. The realist ${ }_{2}$ might correctly observe that the relationship between government and these people can be described as one of domination. ${ }^{4}$ But it is clearly wrong to infer that political relationships in general, throughout the society, should be understood as involving wholesale disagreement over principles and goals, and political decisions, accordingly, simply as exercises of coercive power.

The second reason why political disagreement in contemporary societies may appear deeper than it is to the realist ${ }_{2}$ is that the quarrels taking place between political philosophers over matters of principle are indeed often quite sharp. But this is in the nature of the trade, and may simply reflect the fact that the realist ${ }_{2}$ who sees disagreement everywhere is spending too long in the library reading works of theory and too little time out on the street listening to the voices of the people (or if he cannot do that, examining what social scientific surveys reveal). The political philosopher's job, as conventionally understood, is to convert widely held intuitions about justice and so forth into a coherent theory, and to do this it is going to be necessary to highlight and develop certain parts of the common stock of beliefs at the expense of others (for some good examples of this way of proceeding, see Floyd, 2016). Each philosopher will do this in her own way, and the result, inevitably, is theoretical disagreement. But it is a mistake to project this disagreement back on to the public at large, and suppose that it is disparate mix of covert libertarians, egalitarians, feminists, utilitarians, Rawlsians and so on. Ask the people directly and they are likely to sound like any one of these characters on different occasions, depending on the question that is being asked and the context in which it is being asked. So this is another way in which realism is not realistic $_{1}$ : it is influenced too much by books and articles and too little by reality, in the form here of the political beliefs that people - most of them anyway - actually hold. ${ }^{5}$

Besides overstating the extent to which the public is divided in its beliefs and political attitudes,

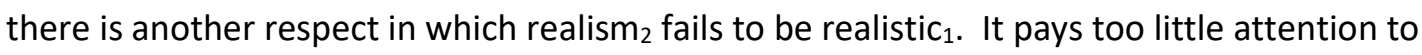
questions of political identity, and especially of national identity. Realism 2 sees individual citizens, and maybe political elites trying to command them, but it does not see horizontal ties between the citizens themselves in the form of allegiances that are not directed at leaders specifically but at the 'imagined community' itself, to borrow Anderson's (1983) phrase. This blindness makes it regard 
the problems of political order and legitimacy as more difficult to solve (internally) than they really are, because it overlooks the powerful resource that nationality supplies to leaders who trade in it ('I am one of yours: I have your interests at heart') to win support and mobilise citizens for collective action. Where a widely shared national identity exists, it also helps to solve the problem of political disagreement, because it motivates people to find positions that everyone (or almost everyone) can agree upon, as well as providing symbols and historical memories that can be used to good rhetorical effect to swing people emotionally behind policies that leaders want to adopt. (There is more to be said in favour of nationality than this, but here I am just presenting the face that realists, given their general preoccupations, ought to have recognized: see Miller, 1995 for a wider defence.) Some argue that the force of national identities, in liberal democracies anyway, is weakening, though here it's important not to confuse a diminishing commitment to existing states with a dilution of national identity, since the people who are turning against the state are often doing so out of a commitment to an alternative national identity, as in the case of sub-state nationalism. It's also true that nationalism is a specific feature of modern political systems, not something intrinsic to the very idea of politics itself, but realists ${ }_{2}$ pride themselves on their understanding of historical contingency, so it is all the more puzzling that this salient feature of contemporary politics should have escaped their attention. It reveals one respect in which realism 2 remains close to the assumptions of the liberal individualism it is trying to displace.

National identities might help to solve the problem of political order internally, but they are often thought, with some justification, to make the problem of international order even harder to solve than it would otherwise be. Hobbes' depiction of the international realm as a state of war, which I cited earlier, rests on the assumption that sovereigns are fearful of each other, and only feel secure to the extent that they are able to protect themselves against attack, perhaps by attacking preemptively themselves (see Hobbes, 1985: 224). Their concern is to be more powerful than their adversaries, in order to ward off invasion, the collective equivalent of violent death for the individual. This is a grim picture, but it is made grimmer still if sovereign states are regarded as representing nations, for then account has to be taken of national aspirations as a further source of conflict. These might involve extending the nation's boundaries outwards in order to recapture part of the nation's 'homeland' that is currently controlled by another state, or else the more diffuse idea of a sphere of influence that requires neighbouring states to recognize the overlordship of the nation in question. There is no need to remind readers that fulfilling such aspirations has often been a very effective way for political leaders to shore up their support domestically. 
International realism of the mid-twentieth century variety was well aware of the significance of nationalism as a force in international relations. Morgenthau, for example, devotes a significant part of Politics Among Nations to a diagnosis of the way in which the rise of nationalism has changed the international order, displacing the ethical system of the 'aristocratic international' which in Europe had hitherto imposed limits on state behaviour - for example, rules governing the conduct of war (Morgenthau, 1954: esp. chs. 16 and 20) Waltz, seeking a philosopher to illuminate the consequences of an international system that lacked a co-ordinating sovereign, chose Rousseau rather than Hobbes, since Rousseau's understanding of the force of patriotism and social unity, prefiguring later nationalism, showed more clearly why self-determination for one state would inevitably bring it into conflict with its neighbours (Waltz, 1959: ch. 6). Niebuhr took it as axiomatic that states would always act on behalf of the nations they represented, and that the only normative guidance worth offering involved pointing out how the 'national interest' could most wisely be pursued (see McKeogh, 1997: ch. 6). Here again, therefore, the cautionary tales that contemporary realists 2 might offer to global political theorists seem less compelling than those supplied by their predecessors from half a century ago.

\section{Global political theory: the agency problem}

Up to this point I have been assessing the merits of recent versions of 'political realism' as applied to politics in general, and have detected some significant weaknesses. I have argued in particular that realism 2 fails in important respects by the standards of realism ${ }_{1}$. But now I want to focus on global political theory and ask whether it might benefit from a greater dose of realism in either of these senses. Of course 'global political theory' is a wide-ranging phenomenon, but I have specifically in mind ambitious theories of global justice and global democracy - bodies of work that are loosely but not tightly connected, since it remains an open and disputed question whether global justice, in the form of global distributive justice, requires global democracy as one of its preconditions. Now these theories can be assessed quite straightforwardly on normative grounds. In both cases they involve taking a political principle that was first elaborated for use in domestic contexts and applying it globally. The assumption here is that the reasons we have to support some principle of distributive justice - say equality of opportunity - or some version of democracy - say liberal democracy - at domestic level apply equally when we move to consider the world as a whole. If equal respect for persons entails that the state should be constituted as a democracy, the same holds for international organizations up to and including world government, for example. Such arguments can be challenged. Reasons can be given why states and the societies they govern have features not possessed by the world as a whole that are relevant when ideals of justice and democracy are being 
defended. This is the general shape of the normative debate about the principles of global political theory. ${ }^{6}$

Looking at this debate through realist spectacles (of either kind) would, however, involve a change of focus. The question would no longer be whether ideals of global justice and democracy are appropriate in the light of possible disanalogies between domestic and international contexts; for the sake of argument, suppose that they are. Instead, the most important questions are going to concern agency and legitimacy. The agency question can be put in the form: who is going to have sufficient reason to try to implement these ideals of justice and democracy internationally? The legitimacy question can be expressed as: why should the peoples of the world accept the institutions that are necessary to deliver global justice and/or democracy as legitimate? Although connected, these questions are not the same, because the first is asking about the motivation to create the institutions in question, starting from where we are now, whereas the second is assuming that the institutions have indeed been created, by some means or other, and asking about whether they could satisfy a global version of Williams' Basic Legitimation Demand.

Let's examine these questions in turn. Who might serve as the agents with reason to promote global justice or democracy, as understood by their advocates? Broadly speaking there seem to be three possibilities: people at large, acting as 'global citizens', states, acting in concert, or organized groups of activists (these are not the only actors on the global stage, but others, such as bodies representing corporate capital, are unlikely to be agitating for justice and democracy). The first of these potential agents, global citizens, would immediately encounter very large co-ordination problems, even if we assume that each individual citizen was sufficiently well-motivated to further the goals in question. I have argued elsewhere that the idea of global citizenship is really an oxymoron, since in the absence of political institutions at global level, the political relationship between persons that defines citizenship cannot exist (Miller, 2013a). Those who advocate global citizenship, or indeed already regard themselves as 'global citizens', are using the term for what is in fact a moral rather than a political relationship - that is, they are urging people to 'think global' in their everyday lives, by acting so as to avoid harming human beings in other places (for example, buying Fair Trade products), or to promote their welfare positively (for example, contributing money to famine relief). Doing these things may well be morally admirable, but it is a far cry from acting collectively to build the institutions that would be needed to deliver a goal such as global equality of opportunity. Collective action requires organization, and some assurance that others are doing their part in the collective endeavour. In short 'people at large' are not even prospectively an agent of the kind that might realise the principles defended by global political theorists. 
States, on the other hand, can take action in concert, and have already done so by setting up such international institutions as currently exist (the UN, the WTO, the ICJ, etc.). The question here is the constraints on their collective action imposed on the one hand by the relationship they stand in towards their own citizens, and on the other by the nature of the international system in its current form. So first, states if they are to remain legitimate vis-a-vis their own populations must act consistently with the broad mandate that the people have given them, and this means that they will have to pay some attention at least to the 'national interest' as conventionally understood. How tight a constraint is this? Looking at the question from a realist perspective, we should recognize that states have considerable resources with which to persuade their populations that the actions they are taking are indeed in the national interest - thus both aid-giving and humanitarian interventions are standardly presented not only as justified on moral grounds, but also as contributing to national security, or national economic goals. What would be harder to justify, however, would be handing over significant amounts of decision-making authority to international institutions. We have already observed in the case of the European Union the extent to which participating states suffer from a popular backlash when they are seen no longer to be able to decide issues that their citizens feel strongly about (such as immigration policy) because these decisions have been removed to a higher level. States have to satisfy legitimacy constraints internally. To do that they have to be seen to pursue policies that advance the basic interests of their citizens. So although this does leave them with some flexibility, as I have suggested, it will be difficult to justify setting up institutions that constrain this role in future: states will insist on vetoes and opt-outs.

They will also be hampered by the competitive nature of the international system itself. Even where it is clear that every state will be a net beneficiary if some global rule or institution is created - for example in relation to climate change - each state will try to manoeuvre to shift the package of benefits and burdens on offer in its favour. ${ }^{7}$ No state wants to lose out relative to others, for reasons that the international realists have emphasized. This may result in no agreement being reached: climate change again offers the obvious example. The question then is whether a sub-set of states will have the motivation and the power to impose international institutions on the remainder. The best example of this may be the gradual evolution of international law, which broadly speaking can be regarded as a case of liberal democracies attempting to establish standards that will apply to the external actions of all states, and in the case of jus cogens norms, regardless of whether these states have formally accepted the norms in question. International law, however, notoriously lacks enforcement mechanisms with teeth. It relies on relatively soft sanctions such as shaming and withdrawal from trade agreements by the sanctioning state. Even though state officials 
can see the advantages of a well-regulated international order, they also want to defend their political autonomy, and to avoid committing to rule or institutions that will later act as significant constraints on that autonomy.

States, therefore, cannot be seen as reliable agents of global principles of justice or democracy. It might be argued in reply that this is true only so long as the great majority of their citizens regard their main role as promotion of the national interest. If citizens became principled cosmopolitans, democratic states at least would have to follow suit. This is true, but it only shifts the problem one stage on: what agency is going to bring about this mass moral conversion? Here we come to the third possibility that is worth considering. Might there be groups, organized either nationally or internationally, that were sufficiently committed to cosmopolitan ideals that they might act as a spearhead, lobbying both citizens and states to promote these ideals. This possibility has been argued for by Lea Ypi (2012: ch. 7), in her defence of the idea of a 'cosmopolitan avant-garde': the remarks follow draw upon my longer discussion in Miller, 2013b. Ypi argues that, looking across the world, we can find groups of activists organized either nationally or internationally, with concrete aims such as boycotting multinationals that employ child labour, defending the rights of immigrants against state practices, or combatting the deforestation of the Amazon basin. These groups serve partly to raise awareness among citizens at large of the global issues in question, and partly to put pressure directly on public officials to take action. Ypi claims that taken together they can be seen as forming an 'avant-garde', since their actions embody the cosmopolitan ideals of the future.

One might be sceptical of the latter claim on the grounds that it assumes that we already know history's direction of motion. If it is indeed the case that history is moving towards 'more just and equitable global institutions', then with the benefit of hindsight we will one day be able to say that these groups formed the progressive vanguard, in the same way that we now celebrate the slavery abolitionists and the suffragettes (these are the examples that Ypi, 2012: 163-5 uses to illustrate the idea of a political avant-garde). But suppose the global future turns out to be neo-liberal: then the 'avant-garde' label will more readily attach to entrepreneurs who create businesses that operate internationally, or the computer programmers who developed the internet. Of course it would be possible to stipulate that a group cannot form part of the avant-garde unless it has the 'correct' global values, but this then abandons the idea of the vanguard as the group marching ahead of the rest of the army, since at this point we cannot say which way the army - the mass of global citizens is actually moving over time.

One might also wonder whether groups with the relatively specific objectives that Ypi mentions can form a cohesive political force, either in terms of organization or in terms of their wider aims. Even 
if they are all aiming to contribute in some way to enhancing global justice, their priorities are different, and might in some cases even conflict - for example activities whose aim is to support immigrants by challenging border controls might not be furthering global equality overall, if the people who are being enabled to move are the people who would otherwise be leading the development of their home societies. Something similar might apply in the case of the consumer Fair Trade movement, if, as has been alleged, its effect is to privilege some producers at the expense of others who cannot meet Fair Trade standards. There are admittedly umbrella organizations, such as Green parties that attempt to develop platforms combining a number of issues - environmental protection, anti-poverty measures, support for indigenous groups, etc. - though the history of radical parties is also a history of internecine strife.

In fact, the most effective agents of global justice and democracy currently operating are probably government officials, lawyers, and others who are using existing intergovernmental institutions to create forms of regulation that states are increasingly disposed to comply with, regardless of the wishes of elected politicians. ${ }^{8}$ Since they are largely working behind the scenes, far from the sight of electorates, this does not qualify as a democratic process, but the result might be described as a weak form of transnational democracy, since in giving their consent to the regulations these agents are regarded as representatives of the participating states. What is being achieved by this means, however, falls far short of the ambitious ideals proclaimed in global political theory.

\section{Global political theory: the legitimacy problem}

So much for the agency question: what now about the legitimacy question? Supposing the institutions needed to deliver global democracy and justice were somehow brought into existence, how would the legitimation demand be met? Note first that we cannot say that the institutions are legitimate precisely because they will help deliver these global goals, because that assumes that we already have agreement among all of the world's peoples on these very goals. That seems unrealistic. There is no consensus, for example, on whether a world government is something we should even be attempting to bring into existence. There is no consensus on whether states have obligations to redistribute their natural resources and accumulated wealth in the name of global equality. Nor do the various mechanisms that have worked over time to produce a large measure of agreement among domestic publics - state institutions, the national media, a common education system - exist at global level. So even a philosopher who herself is committed to one or other of these goals cannot argue that an international institution becomes legitimate simply because it can be shown to promote them. To say that would be to misunderstand the very idea of legitimacy, which is distinct both from justice and from democracy (there can be forms of legitimation that are 
not democratic, as Weber's (2004) classic analysis showed). Instead, what we would need to show, from a realist perspective, is that institutions that are legitimate for other reasons may nonetheless, as a side-effect, help to realise these global principles.

What might these other reasons be? A plausible place to start, highlighted by Terry Macdonald in her contribution to this symposium, is to assume that international institutions are established to solve collective action problems between states: there are shared interests that states and/or their citizens have that cannot be effectively pursued so long as the international order remains anarchic, so setting up an institution allows them to co-ordinate their behaviour. An obvious example would be a regulatory body that issues licenses to fishermen to prevent overfishing in a particular region. By creating the institution and agreeing to comply with its rules, each participating state will do better in the long run, since fish stocks with be preserved for future generations. As a by-product, the allocation of fish will in some sense be fair - each nation gets its allotted quota - whereas the result of a free-for-all might mean some countries losing out entirely.

Although it might be a necessary condition of international legitimacy, however, that an institution should successfully solve a collective action problem, it does not seem to be a sufficient condition. That is because there will typically be a number of alternative ways in which the problem could be solved - different institutional structures, leading to different outcomes in terms of the distribution of burdens and benefits between the parties. ${ }^{9}$ So, to continue with the fisheries case, a state whose fishing fleet was going to be controlled by the regulatory body might complain that it had not been properly represented when the scheme was being drawn up, and as a result was not being given an acceptable quota of fish to catch. This might be a reasonable complaint - thought it would not be reasonable to deny an institution's legitimacy merely because the outcome did not match the state's own conception of what a fair outcome would be (this would be to conflate legitimacy and justice). We need a standard of legitimacy that would select only some of the possible institutional arrangements as creating good reasons for all states to comply with them.

What might this standard be? It is tempting at this point to appeal to democratic principle and say that legitimate international institutions must be democratically constituted. But that temptation should be resisted, in part because it is quite indeterminate what 'being democratically constituted' means in this context, and in part because it would be anomalous to insist that states that are not themselves internally democratic should nevertheless recognize the legitimacy of international institutions by applying that standard. The indeterminacy arises because of the various ways in which states of very different sizes and/or different stakes in the relevant issue area might be represented in the institution, and the alternative procedures - majority, supermajority, unanimity, 
etc. - that it might employ when decisions have to be taken. The choices that are made in institutional design will have predictable results for the content of the decisions that are reached. Another well-rehearsed view is that legitimacy depends on accountability (this idea figures prominently in the illuminating discussion of international legitimacy in Buchanan and Keohane, 2006), but here again the question to ask is who the institution is going to be accountable to, and what should happen if those who are tasked with holding the institution to account should reach contrasting verdicts about its performance. 'Global civil society' is too amorphous an entity to perform this accountability function. It is no doubt a good thing for international institutions to have to give an account of themselves, release data on how far they have met their stated objectives, etc., but doing this is not by itself enough to render them legitimate.

At this point, someone examining international institutions through the lens of realism 2 would have to conclude that they unavoidably fail the legitimacy test. They might still perform a useful function, but they would have to be seen as instruments employed by the more powerful states to impose their will on the less powerful, with the latter having only prudential reasons for complying with their directives (this is often the picture that is painted of the WTO, for example). To demonstrate that legitimacy might still be possible, one would have to abandon two axioms of realism 2 , namely that political actors are always driven by their material interests, including their interests in having and exercising power, and that disagreement over norms and principles is pervasive. As I argued earlier, however, at least in domestic contexts these assumptions could be challenged from the standpoint of realism ${ }_{1}$. Could the same be true in international contexts? One would need to show a) that even in these latter contexts, politics involves more than interest-driven bargaining and b) that even if there is less normative consensus internationally than there is domestically, there are at least some principles that command near-universal assent. And there is indeed evidence of 'discursive engagement' across rival discourses in the formal and informal arenas of international politics (Drysek, 2006). There is evidence that principles of justice and fairness not only can but often do play an important role in international negotiations (Albin, 2001). And finally research has traced the transmission of human rights norms between societies not all of which are liberal democracies (Sikkink, 2011). If international actors sometimes engage in deliberation, understood as argumentative exchange aimed at reaching a consensus among the participants, and if there are indeed principles that these actors regard as authoritative in this context, then we would have the basis for a legitimacy claim: international institutions are legitimate to the extent a) that they help to solve significant collective action problems, b) that their decisions are arrived at through processes that include (genuine) deliberation, and c) that the decisions are guided, or at least constrained, by principles that command near-universal assent. 
What this shows is that a realist ${ }_{1}$, unlike a realist ${ }_{2}$, can at least accept the possibility that legitimate international institutions might come into existence (realism 1 , to recall, insists only that political proposals should be supported by evidence that they can be brought to fruition; unlike realism ${ }_{2}$, it does not rule out justice and rights as possible motivating aims). Does this show that global political theory of the kind under discussion is after all in good working order? By no means, because it would need to be shown - and this is a large further step - that the institutions that passed the legitimacy test would also be institutions that could pursue the goals that global theorists themselves favour. This seems unlikely, so long as the normative consensus that is needed for legitimacy remains thin. We return here to the absence of agreement on goals such as global democracy or global equality. Moreover, even if the legitimacy problem could somehow be solved, we would still need to confront the agency problem: who is going to establish the institutions that would be needed for this purpose?

\section{Conclusion}

I conclude that global political theory would indeed benefit from a dose of realism, even if the view of political possibilities presented by realism $\mathrm{m}_{2}$ is set aside as unduly narrow. It would serve global theory well to think less about how to defend ambitious political ideals on moral grounds, and more about how changes to the international order might be brought about in a way that respects the diversity of moral and political standpoints found among the world's peoples. How large a dose should be administered will depend on the purpose for which the theory is intended - in particular who its audience is supposed to be. This is another issue insufficiently explored in the current literature. ${ }^{10}$ When we produce pieces of domestic political theory, most of us have a reasonably clear sense of the readers we are aiming to reach: citizens at large, and members of the political class who represent them (in practice, of course, we speak mostly to fellow-academics. But I do not believe one can make sense of the very practice of political philosophy unless it has this wider aim). The corresponding answer for global political theory is far less clear: are we attempting to provide guidelines for the foreign policy of one state, or a group of states (liberal democracies, say), or are we setting out principles that might underpin a new global order, and that therefore must be potentially acceptable to all of the members of that order. ${ }^{11}$ Even Rawls (1999), it may be recalled, who was anxious to broaden his intended audience beyond the first group (and who was correspondingly modest in his ambitions) drew the line around 'liberal and decent' societies (for an approach to justice beyond the state that self-consciously restricts itself to principles that could guide the foreign policy of a liberal state, see Blake, 2013). This is a question well worth pondering 
for the future, and the answer we come to will also help to settle how much 'realism' we should ingest as we go about our philosophizing.

\footnotetext{
${ }^{1}$ In his contribution to this symposium, Shmuel Nili (2016), though supportive of the general claim that political philosophers need to take social science much more seriously than they often have, is sceptical that a realist global theory can find such support. Although I largely agree with his argument that the complexity of the global system makes it difficult for social scientists to predict the consequences of institutional or policy changes, I do not think that what he calls the 'one world problem' - the problem that we have no alternatives to compare with the actual world - is insuperable. We can, after all, study different configurations of the global system at different points in time - for example we can examine under what conditions inter-state federations have proved to be stable and when they have not.
}

\footnotetext{
${ }^{2}$ Because of this competitive element, I am sceptical of the currently popular idea that we can distinguish between 'ideal' and 'non-ideal' political philosophy as alternative types of theory that different people can pursue simultaneously without either challenging the other's position. Instead, if we are going to use this distinction, it should be in the way originally proposed by Rawls (1971:
} 245-8), where 'ideal theory' comes first, and then 'non-ideal theory' has the task of working out the principles to be applied and directives to be followed in unpropitious circumstances where the basic principles of justice and the institutions that embody them cannot be fully implemented; for a full discussion, distinguishing different reasons why non-ideal theory is required, see Simmons (2010). The real debate, then, is not over whether to do ideal theory or non-ideal theory - we will almost certainly need to do one after the other - but over how 'realistic' ideal theory ought to be. What are the 'fixed constraints of human life' that must be recognized even under the 'favourable circumstances' for which ideal theory is designed?

\footnotetext{
${ }^{3}$ In his contribution to this symposium, Christopher Bertram (2016) further divides moralist views into 'principle-based' and 'model-based' political theories, and suggests, contrary to what one might at first think, the latter are less realistic than the former, since if the conditions specified in the model are not fully met in the actual world, the model's normative entailments will be irrelevant. However this assumes that those, like Rawls, who fall into the 'model-based' category, cannot distinguish between, say, cases in which the conditions are largely fulfilled and cases in which they
} 
are barely fulfilled at all, and then draw the appropriate practical conclusions, which is what Rawls (1971: ch. 6) himself appears to be doing when he distinguishes between societies that are 'nearly just' and those that are not, or later in Rawls (1999) between 'liberal societies', 'decent societies', 'burdened societies' and 'outlaw states'.

${ }^{4}$ Williams (2005b: 136) recognizes that no political order will be recognized as authoritative by everyone under its dominion. For a fuller discussion of Williams' treatment of people who won't accept the legitimation narrative that is offered to them, see Sleat, 2013: 123-6.

${ }^{5}$ Reading some parts of the realist literature brings to mind a remark of Burke's in which he warns his French readers not to take too seriously the writings of the English political radicals: 'Because half a dozen grasshoppers under a fern make the field ring with their importunate chink, whilst thousands of great cattle, reposed beneath the shadow of the British oak, chew the cud and are silent, pray do not imagine, that those who make the noise are the only inhabitants of the field'. (Burke, 1986: 181). My complaint about the realists 2 , then, is that they pay too much attention to the quarrelsome grasshoppers, and fail to investigate what the cattle might think, or might do once aroused.

${ }^{6}$ It is summarised in both Christopher Bertram's (2016) and Matthew Sleat's (2016) contributions to this symposium. Sleat, however, charges that both sides of the debate are equally guilty of 'moralism', insofar as the debate focuses on the scope of justice, which according to Sleat is regarded by both as a 'moral question'. He concedes, however, that those who adopt the 'statist' position on the scope of distributive justice recognize explicitly that it is the coercive relationship between a state and its subjects that raises the demand for legitimation by appeal to justice, and in this respect the view of someone like Thomas Nagel (2005) appears very close to that of Bernard Williams, with his 'Basic Legitimation Demand'. But the question may then just turn on wider and narrower ways of understanding 'morality', where the wider understanding encompasses the idea of 'political morality' as the set of norms that are appropriate to govern political life specifically, in contrast to 'individual morality'.

${ }^{7}$ Moreover in doing so they will typically be able to appeal to principles that support their case, not just to naked self-interest. In his contribution to the symposium, Aaron James (2016) suggests that participants in a policy-making practice may be guided by principles whatever their personal aims if they perceive that these principles are endorsed by enough other members. Suppose we apply this 
analysis to an international practice such as trade or climate change negotiations. There is a shared understanding that the aim of the practice is to produce an agreement from which every state will benefit. Nevertheless there are different ways in which costs and benefits can be distributed, and competing principles of fairness in distribution, each with some degree of plausibility (as I have argued in Miller, 2009 and Miller, Forthcoming a, respectively). We may expect officials involved in these negotiations to coalesce around the principle that is most favourable to the interest of the states that they represent - thus there is no guarantee that an agreement can be reached even if all the participants are guided by 'fairness' as they see it.

${ }^{8}$ It is an interesting question what motivates these public servants to act in this way. My guess is that there are three main contributory factors: first, they tend to come from elite educational backgrounds in which liberal-cosmopolitan political values are inculcated; second, they are insulated from having to win the endorsement of mass electorates; third, they interact frequently with one another across national boundaries in conferences, negotiations, and so forth, which will tend encourage the emergence of a shared normative framework. In f.n. 13 I expressed doubts as to whether this would be sufficient to override conflicts of national interest, but there are policy areas - human rights is the obvious example - where these competing interests are less obviously at stake. For further reflection on the social roots of contemporary cosmopolitanism, see Calhoun (2002).

${ }^{9}$ In her contribution to this symposium, Terry Macdonald (2016) emphasizes disagreements over ends as a major obstacle to institutionalized collective action. About this she is undoubtedly right, since even in a case such as the one envisaged in the text where the object of the collective action is relatively clear and narrow, there will undoubtedly be knock-on effects that impact other policy goals. I am less convinced that the fluidity of ends is a major problem, once it is recognized that we are primarily concerned with collective action among states, since (as has often been observed) states develop longstanding policy aims that survive changes of government personnel. In this context, Geuss's observations about the indeterminacy of individuals' aims and values do not seem apropos.

${ }^{10}$ It is touched upon briefly towards the end of Mathias Risse's (2016) contribution to this symposium, where he suggest that in the global context political philosophers should move from seeing themselves as 'citizen-discussants' to seeing themselves as 'global discussants'. But more needs to be said here about whether it is indeed possible to develop a form of 'global public reason' of comparable power to public reason in the domestic case. 
${ }^{11}$ In his contribution to this symposium, Jonathan Floyd (2016) adopts the second view, and it might appear that this is precisely what it means to do 'global political theory'. But it seems to me that the 'global' in 'global political theory' really refers to the subject matter or content of the theory -i.e. principles that address global issues, or have global scope - and not to the audience for whom the theory is written. Indeed someone of a realist disposition might think that the prospects for global political theory were pretty dim if the theory had to engage with the political beliefs of everyone, regardless of their cultural or political background. Floyd attempt to avoid this problem (which he recognizes) by appealing to people's behaviour rather than their beliefs as the test of the acceptability of political institutions. But the fact that people who live in egalitarian liberal democracies rebel against them less than do people who live under alternative systems doesn't settle the issue, because we are dealing here with two different sets of people, socialized in different ways, not with the same people exposed to rival political systems. People subjected to autocracies or theocracies might in fact prefer these systems, even though they wanted to kick out the current rulers.

\section{References}

Albin C (2001) Justice and Fairness in International Negotiation. Cambridge: Cambridge University Press.

Anderson B (1983) Imagined Communities: reflections on the origin and spread of nationalism. London: Verso.

Baderin A (2014) Two Forms of Realism in Political Theory. European Journal of Political Theory 13 (2014): 132-5.

Bertram C (2016) Realism, Moralism, Models and Institutions. Journal of International Political Theory.

Blake M (2013) Justice and Foreign Policy. Oxford: Oxford University Press.

Buchanan A and Keohane R (2006) The Legitimacy of Global Governance Institutions. Ethics and International Affairs 20: 405-37. 
Burke E (1986) Reflections on the Revolution in France (ed CC O'Brien). Harmondsworth: Penguin.

Calhoun C (2002) The Class Consciousness of Frequent Travelers: Toward a Critique of Actually Existing Cosmopolitanism. South Atlantic Quarterly 101: 869-97.

Drysek J (2006) Deliberative Global Politics: discourse and democracy in a divided world. Cambridge: Polity Press.

Finlayson L (forthcoming) With radicals like these, who needs conservatives? Doom, gloom, and realism in political theory. European Journal of Political Theory Online First: 1-19.

Floyd J (2010) Should Political Philosophy be more Realistic?. Res Publica 16: 337-47.

Floyd J (2016) Normative Behaviourism and Global Political Principles. Journal of International Political Theory.

Galston W (2010) Realism in Political Theory. European Journal of Political Theory 9: 385-411.

Geuss R (2008) Philosophy and Real Politics. Princeton, NJ: Princeton University Press.

Hobbes T (1985) Leviathan (ed CB Macpherson). Harmondsworth: Penguin.

Horton J (2010) Realism, Liberal Moralism and a Political Theory of Modus Vivendi. European Journal of Political Theory 9: 431-48.

Honig B and Stears M (2011) The New Realism: from modus vivendi to justice. In: Floyd J and Stears M (eds) Political Philosophy versus History: contextualism and real politics in contemporary political thought. Cambridge: Cambridge University Press, pp. 177-205.

James A (2016) How Cynical can Ideal Theory Be?. Journal of International Political Theory.

Macdonald T (2016) Institutional Facts and Principles of International Political Legitimacy. Journal of International Political Theory. 
McKeogh C (1997) The Political Realism of Reinhold Niebuhr. Basingstoke: Macmillan.

Miller D (1995) On Nationality. Oxford: Clarendon Press.

Miller D (2009) Global Justice and Climate Change: how should responsibilities be distributed? Parts I and II. Tanner Lectures on Human Values 28: 119-56.

Miller D (2013a) The Idea of Global Citizenship. In: Ben-Porath S and Smith R (eds) Varieties of Sovereignty and Citizenship. Philadelphia: University of Pennsylvania Press, pp. 227-43.

Miller D (2013b) Lea Ypi on Global Justice and Avant-garde Political Agency: some reflections. Ethics and Global Politics 6: 93-99.

Miller D (Forthcoming a) Fair Trade: What does it Mean and Why does it Matter? Journal of Moral Philosophy.

Miller D (Forthcoming b) In What Sense must Political Philosophy be Political?. Social Philosophy and Policy.

Morgenthau H (1954) Politics Among Nations. $2^{\text {nd }}$ ed. New York: Alfred A. Knopf.

Nagel T (2005) The Problem of Global Justice. Philosophy and Public Affairs 33 (2005): 113-47.

Niebuhr R (1940) Christianity and Power Politics. New York: Charles Scribners Sons.

Niebuhr R (1953) Christian Realism and Political Problems. New York: Charles Scribners Sons.

Nili S (2016) Global Justice and Global Realities. Journal of International Political Theory.

Philp M (2012) Realism without Illusions. Political Theory 40 (2012): 629-49.

Rawls J (1971) A Theory of Justice. Cambridge MA: Harvard University Press. 
Rawls (1999) The Law of Peoples. Cambridge, MA: Harvard University Press.

Risse M (2016) What Difference can it Make; Why Write Books on Global Justice in the First Place? Journal of International Political Theory.

Rossi E and Sleat M (2014) Realism in Normative Political Theory. Philosophy Compass 9 (2014): 689701.

Sikkink K (2011) The Justice Cascade: how human rights prosecutions are changing world politics. New York: W.W. Norton.

Simmons AJ (2010) Ideal and Nonideal Theory. Philosophy and Public Affairs 38 (2010): 5-36.

Sleat M (2013) Liberal Realism: a realist theory of liberal politics. Manchester: Manchester University Press.

Sleat M (2016) Global Justice as a Political Value. Journal of International Political Theory.

Waltz K (1959) Man, the State and War. New York: Columbia University Press.

Weber M (2004) The Three Pure Types of Legitimate Rule. In Whimster S (ed) The Essential Weber. London: Routledge, pp. 133-45.

Williams B (2005a) Realism and Moralism in Political Theory. In: Williams B In the Beginning was the Deed: realism and moralism in political argument (ed G Hawthorn). Princeton NJ: Princeton University Press, pp. 1-17.

Williams B (2005b) Toleration, a Political or Moral Question?. In: Williams B In the Beginning was the Deed: realism and moralism in political argument (ed G Hawthorn). Princeton NJ: Princeton University Press, pp. 128-38.

Ypi L (2012) Global Justice and Avant-Garde Political Agency. Oxford: Oxford University Press. 